\title{
POLITICAL AND MUNICIPAL LEGISLATION IN I9OI
}

Constitutions.-A new constitution has been adopted by Alabama, and at the close of IgO I constitutional conventions were in session in Virginia and Connecticut. After many years of agitation the question of revision of the Connecticut constitution was submitted to the voters. Great inequality in representation was the evil most complained of, but as the legislature provided for a convention based on representation even more unequal than that composing the present legislature, it was hardly to be expected that the existing inequality would be corrected. The present constitution, adopted in I8I8, provides a fixed apportionment of representation, each town having not more than two nor less than one representative. With the redistribution of population accompanying the industrial development of the present century this fixed apportionment became grossly unequal. At present the thirteen cities of the state containing over one-half of the total population have but one-tenth of the number of representatives in the lower house, only twenty-six of the 252 representatives being from these cities. This inequality is even more clearly shown from the fact that the town of Union, with but 428 inhabitants, is entitled to as many representatives as New Haven, the largest city in the state, having a population of 108,000 .

The new constitution of Alabama exhibits the marked increase in bulk common to all recent constitutions, being about twice as long as the previous one of 1875 . The New York constitution of 1894 is three and a half times as long as the previous constitution of 1846 . The new Alabama constitution makes numerous incursions into the proper field for legislative regulation, substitutes quadrennial for biennial sessions, and imposes many important restrictions on the power of the legislature, particularly in regard to special legislation. Though prohibiting special legislation on the part of the legislature, the new constitution itself contains special legislation of the most pronounced type. This is especially true of the sections regulating local taxation and indebtedness. In a constitution so detailed in nany parts there will doubtless be frequent need for amendments. In most of these the voters have no interest and can not be expected to vote on them intelligently, yet each amendment will have to receive a three-fifths vote of the legislature and a majority of all the electors

$$
\text { [370] }
$$


voting at the election. There is need for some delimitation of the proper sphere for constitutional regulation and a strong public opinion that will hold constitution-makers to their proper function.

Constitutional Amendments.-The Pennsylvania legislature of I899 passed two resolutions proposing amendments to the state constitution. Governor Stone construed the provision of the state constitution providing that every order, resolution or vote, to which the concurrence of both houses may be necessary, shall be presented to the governor for approval, as giving him the right to veto the proposed constitutional amendments. The state Supreme Court, however, has decided that this provision refers merely to ordinary legislation, and has no reference to the action the two houses may take in performing their part of the work of creating amendments. This is the construction that has been placed on similar provisions in the constitutions of other states. ${ }^{1}$

To facilitate voting on constitutional amendments, Nebraska ${ }^{2}$ has provided that if the state convention of a political party declares for or against a proposed constitutional amendment such declaration shall be considered a portion of the party ticket. A straight vote for the ticket will then count as a vote for or against the amendment. In Nebraska, as in a number of other states, not only simply a majority of those voting on amendments is required, but a majority of all the votes cast at the election. Many voters favoring an amendment neglect to vote on it, so that amendments often fail even though there be little opposition to them. By making the amendment a portion of the party ticket this difficulty will be obviated.

State Boards and Commissions. ${ }^{3}-$ For about twenty years the movement toward the multiplication of state boards and commissions has been very strong. With the demand for state supervision or aid in each new matter a new board or officer has been created. That this movement is still in progress is shown by the fact that during IgOI at least forty new boards and officers were created by the various legislatures. Accompanying this movement, however, a movement toward the consolidation of boards and officers has been developed during the past few years. Centralized boards of control

${ }^{1}$ Commonwealth vs. Griest, $196 \mathrm{~Pa} .39^{6}$.

2 Nebraska, rgor, ch. 29.

${ }^{3}$ See C. E. Merriam, State Government, in Review of Legislation, rgor, p. I5, New York State Library Legislation Bulletin, No. 16. 
of state institutions have been created in a number of states, and during I90I in New York the Forest preserve board was combined with the Forest, Fish and Game commissions, ${ }^{4}$ and the functions of the commissioner of labor statistics, factory inspector, and board of mediation and arbitration consolidated under a commissioner of labor. ${ }^{5}$

Uniform Legislation.-California ${ }^{b}$ has repealed its act creating a commission to promote uniform legislation, and Pennsylvania ${ }^{7}$ has just created a commission, consisting of three members, appointed by the governor for a term of four years. The Uniform Negotiable Instruments Law, approved in 1896 by the National Conference of State Commissioners on Uniform Legislation, was adopted in Igo I by Pennsylvania, ${ }^{8}$ making in all sixteen states that have adopted the act. A Code Commission in Arizona adopted the act and submitted it to the legislature of Igor as part of the new code, but the legislature saw fit to revise it, thus thwarting the attempt at uniformity.

The need of more uniform laws is being felt more and more each year. Differences in mere matters of detail and forms of procedure are the most frequent causes of annoyance and injustice. While it can not be expected that states very differently situated will be able to agree on controverted questions of public policy, there is no excuse for diversity in matters of detail and procedure in which uniformity would be advantageous. Many national conferences, meeting during the past year, have adopted resolutions urging greater uniformity in the legislation affecting the subjects in which they are interested. The National Association of State Librarians adopted resolutions favoring greater uniformity in the preparation and publication of the session laws. The tax conference of the National Civic Federation, held at Buffalo, took steps to bring about uniformity and interstate comity in tax laws. The one point of agreement in testimony before the United States Industrial Commission in regard to labor, transportation, corporations, mining, and agriculture, was the demand for uniform legislation.

4 New York, I901, ch. 94.

'New York, Igor, ch. 9.

- Califomia, r897, ch. 80.

7 Pennsylvania, rgor, ch, rgr.

8 Pennsylvania, roor ch. r6z. 
Publication of Session Laws.-The Michigan constitution, ${ }^{3}$ adopted in 1850 , provides that every newspaper in the state which shall publish all the general laws of any session within forty days of their passage shall be entitled to receive a sum not exceeding $\$ I 5$ therefor. Conditions in the state have so changed that at present only in case of a special session, can the laws be published at a profit for the amount prescribed in the constitution. The state, however, held a number of special sessions during I 898 to I900, and the amount required to pay for the publication of the laws was a considerable item. The legislation of I90r, therefore, submitted to vote in 1902 a constitutional amendment, abolishing payment for publishing the laws in the newspapers. ${ }^{10}$ Several states still continue the very expensive plan of publishing session laws in newspapers. In New York the acts are published in two newspapers in each county. This is an enormously extravagant and totally inadequate method of securing prompt publication. Very few people ever think of reading or preserving these interminable columns, and the system has to recommend it little except the large amounts of public money which it puts into the pockets of publishers of active party organs. One-half the money wisely spent might accomplish vastly better results. The demand for prompt publication is satisfied by the method employed in New York, Connecticut, Massachusetts, Nevada, New Jersey, Ohio and Wyoming, of issuing the laws in separate or unbound form as fast as they are signed by the governor. The European states generally issue their laws in separate or unbound form as soon as signed and printed, and consequently an American can examine current German and Austrian laws much sooner than those of neighboring states, or, in some cases, even of his own state.

Veto Power.-In the revision of the Pennsylvania constitution of 1873 a provision was inserted empowering the governor to veto specific items in appropriation bills. The governors of Pennsylvania have construed this provision at various times as giving them power not only to veto specific items but also to veto a part of a specific item. Until the past year, however, this construction has been considered very doubtful, and only used in exceptional cases. In 1899 the legislature, in its general appropriation bill, ${ }^{11}$ appropri-

- Constitution, Art. 4, Sec. 35.

in Michigan, r 901, p. 380 .

11 Pennsylvania, I 899 , ch. 320 , Sec. 8. 
ated \$II,000,000 for public schools, and Governor Stone vetoed $\$ 1,000,000$ of this appropriation. The Supreme Court, in its decision of April 22, Igor, sustained the veto of the governor. ${ }^{12}$ This decision is something of a surprise, as a number of other states have similar constitutional provisions, but they have never been construed to give the governor power to approve of a portion of an item while disapproving of another portion. Governor Stone, in passing on the appropriation bills of I9OI, made extensive use of the power established by this decision, vetoing parts of 132 different items as well as forty-seven items in their entirety. It is very evident that the power to veto a part of a specific item of an appropriation bill enormously increases the power and influence of the governor, both over legislation and over the entire state administration. There is certainly great need for the centralization of responsibility in state government. The election of many state officers and the appointment of others for long terms without the power of removal renders it difficult to fix responsibility. A certain degree of harmony between the forty or fifty practically independent administrative departments is only secured through the agency of an extra-governmental institution, the political party.

Direct Legislation.-The referendum amendment adopted by South Dakota in 1898 provides that the referendum may be demanded on any law enacted except laws which may be necessary for the immediate preservation of the public peace, health and safety, and the support of the state government and its existing institutions. In a recent case the state Supreme Court has decided that the legislature having declared the provisions of an act necessary for the immediate preservation and support of the existing public institutions of the state, that declaration is conclusive on the court. ${ }^{13}$ Under this decision, therefore, the right to the referendum is practically optional with the legislature. A possible remedy would be to permit a referendum on the repeal of all laws enacted under the emergency clause within ninety days of the time of their going into effect.

Utah adopted an initiative and referendum amendment in 1900, but the legislature of IgOI refused to pass the necessary legislation to put the amendment in effect. Oregon will submit an initiative and referendum amendment to vote in June, I902, which is suf-

19 Commonwealth vs. Barnett, 48 A. 976 .

18 State vs. Bacon, 85, N. W., 605 . 
ficiently complete in its provisions not to need legislation to put it in effect. It applies to state legislation only, and provides for the initiative on petition of eight per cent and the referendum of five per cent of the electors. ${ }^{14}$

Nevada ${ }^{15}$ has referred to the legislature of 1903 an amendment, providing that whenever ten per cent of the electors petition that any law passed by the legislature be submitted to the people, the state officers charged with the duties of announcing and proclaiming elections shall submit the law to popular vote at the next general election. If the electors disapprove, the law is repealed, but if they approve, it can not be repealed or in any way made inoperative except by direct vote of the people. The object of this latter provision is not very clear. It makes it impossible to alter, except by the cumbersome method of direct vote, any act once approved by the people. Aside from this feature, the proposed referendum seems more simple and effective than any yet considered.

An act providing for a mere expression of opinion by electors on questions of public policy has been adopted by Illinois. ${ }^{16}$ On petition of twenty-five per cent of the registered voters of any town, village, city, county, or school district, or of ten per cent of the registered voters of the state, it is the duty of the proper election officers to submit any question of public policy at any general or special election. The number of petitioners required seems sufficient to prevent the abuse of the privilege, and it seems probable that its occasional exercise may prove very advantageous.

Restriction of Legislative Power.-The trend of constitutional enactment is strongly toward the restriction of legislative power. New York $^{17}$ has adopted a constitutional amendment forbidding the legislature to pass special laws exempting persons or associations from taxation, and Oregon ${ }^{18}$ has referred to the next legislature a constitutional amendment prohibiting the formation of corporations by special laws. In view of the gross abuse of the power of special legislation by the Alabama legislature, it is not a matter of surprise that the new constitution adopted during the present year contains drastic restrictions on this form of legislation. Special, private or

14 Oregon, 1901, p. 476.

15 Nevada, 1901, p. 139.

${ }^{16}$ Illinois, 190I, p. I98.

${ }^{17}$ New York, 1901, p. 1803 .

${ }^{18}$ Oregon, 190I, p. 47 I. 
local laws are not to be passed in certain cases specified in thirty-one sub-divisions. ${ }^{19}$ In addition, special acts are not to be passed in cases provided for by general law, or when the relief sought can be given by any court of the state, or unless notice of application therefor is published in counties where the matter affected is situated, at least once a week for four weeks. To make impossible the evasion of these restrictions through judicial interpretation, the meaning of general, local and private law is defined as follows:

"A general law within the meaning of this article is a law which applies to the whole state; a local law is a law which applies to any political sub-division or sub-divisions of the state less than the whole; a special or private law within the meaning of this article is one which applies to an individual, association or corporation."20

Alabama was, in I846, among the first states to change from annual to biennial sessions of the legislature, and is now the first to change from biennial to quadrennial sessions. The new constitution provides for a regular session, limited to fifty days, once every four years. ${ }^{21}$ Special sessions, limited to thirty days, may be called by the governor, but no acts may be passed, other than those designated in the governor's proclamation calling the session, except by a two-thirds vote. ${ }^{22}$

A growing distrust of the legislature is evidenced in the constitutional history of almost every American state. What this will finally lead to is impossible to foretell. If it continues unchecked, the state legislature will follow the city council to decay, impotence and general uselessness. It is not believed that this will be the outcome, as the function of the legislature is indispensable to the best representative government. What must come, however, is a better recognition of the true sphere of legislation, and a better organization for the work of law-making. The work of legislation should be so organized that every relevant fact in comparative politics, history and science would aid in the consideration of each important measure. This implies, among other things, that the legislature should make constant use of the services of experts of all kinds. The great work of the United States Industrial Commission is an indication of what may be accomplished in this way. Every legislative committee

\footnotetext{
19 Alabama Constitution, Sec. ro4.

${ }^{20}$ Alabama Constitution, Sec, I 10.

1 Constitution, Sec. 48.

22 Constitution, Sec. 78, I 22.
} 
should have as its secretary a man specially trained in the subjects considered by the committee, and capable of organizing a thorough scientific investigation of any subject referred to it. This is only an example of what is needful in order that the legislature may perform its functions in the most effective and satisfactory manner, and thus allay the growing distrust that is bringing about such a rapid restriction of legislative powers.

Bill Drafting.-Connecticut ${ }^{23}$ has revised its law relative to the powers and duties of the Clerk of Bills. It is made his duty to assist members of the general assembly in drafting bills of a public nature. Every bill favorably acted on by any committee must, before being reported, be first submitted to the Clerk of Bills, who shall examine it "in respect to its form for the purpose of avoiding repetitions and unconstitutional provisions, and insuring accuracy in the text and references, clearness and conciseness in the phraseology, and the consistency of statutes."

Direct Vote for United States Senator.-Though many state legislatures have at various times adopted resolutions in favor of the election of United States senators by popular vote, and the national House of Representatives has four times voted in favor of the change, the Senate has refused to take action. In order to compel action, a movement was started by Pennsylvania, in $1899,{ }^{24}$ to secure an application, on the part of two-thirds of the legislatures, for the calling of a constitutional convention. As a result of this movement, twelve states, in I9OI, applied to Congress to call a constitutional convention for the consideration of the question of the direct election of senators, and two of these states, Oregon ${ }^{25}$ and Washington, ${ }^{26}$ have, in their application, not limited the convention merely to the consideration of this question.

Election of senators by direct vote would certainly relieve the legislature, and in fact the entire state government, of a most disturbing element, and would tend to strengthen the legislature for the performance of its true function. The best governmental and party organization will be furthered by a greater separation of municipal, state and national politics.

\footnotetext{
${ }^{23}$ Connecticut, rgor, ch. I.

34 Pennsylvania, 1890, p. 418.

25 Oregon, I901, j. r. 5.

26 Washington, 190T, ch. r64.
} 
Suffrage.-The chief problem before the Alabama constitutional convention was that of negro suffrage. The solution reached is similar to that reached by Louisiana in 1898 and North Carolina in 1900. Registration and the payment of a poll tax are required. Before December 20, 1902, any person may register who comes under any of the following classes:

I. Those who have honorably served in land or naval forces of United States in war, or of Confederate states, or Alabama in Civil War.

2. Lawful descendants of persons who served as above.

3. All persons who are of good character and who understand the duties and obligations of citizenship under a republican form of government. ${ }^{27}$

Unless disqualified for some special reason, any person registered before January I, 1903, remains an elector for life, and need not register again except on change of residence, when he may register on production of certificate. ${ }^{28}$

Between December 20, 1902, and January I, 1903, there is to be no registration, and after that date the applicant for registration must come under one of the following classes:

I. Those who can read and write any article of the United States constitution in the English language, and have worked at some lawful employment, business, occupation, trade or calling for a greater part of year next preceding registration, if not physically unable to work.

2. Those unable to read and write, if such inability is due solely to physical disability.

3. Resident owner, or husband of woman who is owner, of forty acres of land.

4. Owner, or husband of woman who is owner, of real or personal property assessed at $\$ 300$.

Registration.-Pennsylvania ${ }^{29}$ has adopted a greatly-needed constitutional amendment, enabling the legislature to require personal registration in cities, and West Virginia ${ }^{30}$ has submitted to vote in 1902 a similar amendment. Voters in Missouri cities of

27 Alabama Constitution, Sec. 180.

${ }^{28}$ Alabama Constitution, Sec. 187.

29 Pennsylvania, r901, ch. 236.

80 West Virginia, r9or, ch. 154. 
25,000 to 100,000 absent on registration day have been granted the right to register by filing a sworn affidavit. ${ }^{31}$

Voting Machincs.-A constitutional amendment permitting the use of voting machines has been adopted by Pennsylvania, ${ }^{32}$ and a similar amendment will be submitted to the people of California ${ }^{33}$ at the next general election. Connecticut, ${ }^{34}$ in 1895 , authorized the use of McTammany and Myers machines at local elections, and has, during Igor, created a commission to examine voting machines, consisting of three members, appointed by the governor for two years. Towns may adopt approved machines in all elections, and it is the duty of the secretary of state to prescribe rules for their use. ${ }^{35}$ The Rhode Island law of 1900 , chapter 744 , creating a voting machine commission to examine machines and make regulations for their use, has been repealed, and a law passed providing that voting machines may be used at all elections. ${ }^{36}$

Indiana, Maine and Wisconsin have been added to the list of states having voting-machine commissions. The Indiana ${ }^{37}$ commission is a bipartisan board of three members, appointed by the governor for a term of four years. The Maine ${ }^{38}$ commission consists of the secretary of state, the attorney-general, and a member of the governor's council designated by the governor. In Wisconsin ${ }^{39}$ the commission is composed of three members, appointed by the governor for terms of five years; two of the members must be mechanical experts. Indiana ${ }^{40}$ had already authorized the use of voting machines at all elections in 1899.

Corrupt Practices.-Michigan ${ }^{41}$ has repealed its corrupt practices act of $189 \mathrm{r}$. This act was based on the earlier act of New York in 1890 , the only advance being that party committees were also required to report receipts and expenses.

Political Parties.-In the general reorganization of political parties in Colorado in 1896 numerous controversies arose as to the

\footnotetext{
31 Missouri, rgor, ch. 145.

32 Pennsylvania, rgor, ch. 242.

3s California, r 901, p. g60.

${ }^{34}$ Connecticut, $1895, \mathrm{ch} .203,335$.

35 Connecticut, I901, ch. 120.

${ }^{36}$ Rhode Island, r gor, ch. 859.

${ }^{87}$ Indiana, I $901, \mathrm{ch} .260$.

${ }^{38}$ Maine, r901, ch. 169 .

${ }^{30} \mathrm{Wisconsin,} \mathrm{I901,} \mathrm{ch.} 459$.

4. Indiana, I $890, \mathrm{ch}$. I 55 .

41 Michigan, r891, ch. roo.
} 
regularity of primaries and conventions, many of which finally came before the courts for decision. An act of $I^{90 I^{42}}$ takes from the courts the settlement of all party controversies, and places it in the hands of the state central committee or the state convention. California ${ }^{43}$ also has enacted that the state central committee may itself, or through its executive committee, decide between rival organizations claiming to represent the party in any sub-division of the state, and such decision shall be final.

Fusion.-Kansas ${ }^{44}$ and South Dakota ${ }^{45}$ have passed laws designed to make fusion more difficult by providing that no person may accept the nomination of more than one party for the same office, and can be placed on the official ballot as the candidate of but one party. In order to effect a fusion, therefore, one of the parties will have to consent to lose its identity.

Primary Elections.-A constitutional amendment, adopted in I9oo, empowered the California legislature to regulate primary elections by general or special laws, and to determine the conditions on which electors and parties may participate in such elections. Taking advantage of the broader powers granted by this amendment, the legislature of I9OI has revised the primary election law of $1899{ }^{46}$ The new act provides for a primary election, to be held at the same time and place, and under the same officers, for all parties casting three per cent of the vote. The expense of the primary is a public charge, and the primary is under the supervision of the local boards of election commissioners and the judges and clerks appointed by it. Separate ballots are provided for each party. The act is mandatory in cities and counties having a population of 7,500, and may be adopted by other localities by a majority vote. The Illinois primary law of 1898 has been revised..$^{47}$ Connecticut ${ }^{48}$ has provided that, after 1902, only enrolled voters can participate in a party caucus. Application for enrollment may be made in person or in writing.

Test of Party Allegiance.-The test provided by the new Cali-

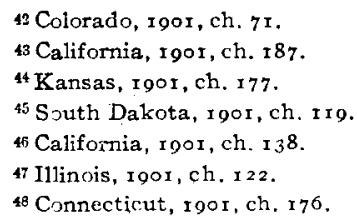


fornia primary law is a bona fide present intention of supporting the nominees of the party at the ensuing election. The Illinois primary act provides that any person offering to vote must be a member of the particular party, and he shall not be deemed a member if he has signed a petition for the nomination of an independent candidate to be voted for at the next regular election, or if he has voted at the primary election of another party within the period of one year next preceding. In a new act $^{49}$ regulating primaries in the two counties containing the cities of Indianapolis and Evansville the qualifications of voters are prescribed as follows:

"Each qualified legal voter of the precinct who, at the last election, voted for the regularly-nominated candidates for the party, and affiliated with the party holding such election, shall be entitled to vote at such election."

The Minnesota direct nomination law $^{50}$ provides that each registered voter shall be entitled to vote with the political party with which he declares that he affiliated, and whose candidates he generally supported at the last general election and with which he proposes to affiliate at the next election.

Direct Nominations.-The act of 1899 , providing for direct nominations in Minneapolis, has been extended to apply to all officers chosen wholly within any sub-division of the state.51 The law of I 899 provided that the elector should be given a ballot of each party, and that he could vote whichever ballot he wished with no declaration as to party affiliation. This provision has been changed, because it opened the way to the participation by members of one party in the nominations of another. It made it possible for the members of a party in which there was no decided contest for a particular office to aid in bringing about the nomination on the opposing ticket of the man whom they considered the weakest candidate. Though the system of direct nomination has long been in use in various parts of the United States, as a result of the Minneapolis experiment, a great deal of publicity was given to the system and a strong sentiment in favor of its adoption created in many states. During the legislative sessions of I9OI bills providing for direct nominations were introduced in a number of states, and in Massachusetts. Michi-

49 Indiana, I901, ch, 219.

60 Minnesota, rgor, ch, 216.

51 Minnesota, I901, ch. 216. 
gan and Oregon acts were passed, making mandatory the use of direct nominations. The Massachusetts act applies only to nominations for state senator and for members of the state committee in each of the Suffolk County senatorial districts. ${ }^{52}$ A special act of the Michigan legislature provides for the direct nomination of city officers and members of the state legislature in Grand Rapids.

Oregon $^{53}$ passed an act, mandatory in Portland and the county in which it is situated and optional with the party committees in other counties, but the act was declared unconstitutional. This law was more thorough-going in its provisions than any heretofore adopted. It provided not only for direct nominations of candidates for public office, but also for direct elections of all party officers and of delegates to congressional and state conventions, and for the formulation and enactment by the party members themselves of every rule and regulation relative to party administration and every declaration of party principle or policy.

Direct nominations are now very popular with certain reformers, but it is not believed that they will prove satisfactory. Ordinarily the convention system is the best method of nominating the numerous candidates required by our governmental system. It is only in very exceptional cases, when the party organization is determined to prevent the nomination of a popular favorite, that a system of direct nominations is superior to that of conventions. This emergency may be provided for by a device that may be called the optional referendum in party nominations. Under this system no nomination by a party convention will become the nomination of the party if within a certain time a petition, signed by a certain percentage of the enrolled voters of the party, is presented, asking that the nomination be made by direct vote of the enrolled party members. It is not probable that the occasion for the actual use of this referendum would often arise, yet the constant possibility of its exercise would prove highly advantageous. The serious threat of the referendum would ordinarily be sufficient either to lead the organization to accept a compromise, or to make the nomination that seemed to be demanded by a majority of the party.

Mounted Police.-Arizona ${ }^{54}$ and Texas ${ }^{55}$ have reorganized their

\footnotetext{
59 Massachusetts, I001, ch. 402.

${ }^{53}$ Oregon, 1901, p, 400 .

${ }^{54}$ Arizona Revised Statutes, 1901, sec. 3213-3230.

${ }^{56}$ Texas, r 190r, ch. 34 .
} 
ranger force. The Texas act provides that the governor may organize a ranger force to protect "the frontier against marauding and thieving parties and for the suppression of lawlessness and crime throughout the state." The force may consist of four companies, of twenty privates, one captain and one first sergeant each. The officers and privates have the powers of peace officers, and must aid the regular civil authorities in the execution of the laws. The captains of the companies and the quartermaster for the entire force are appointed by the governor, and may be removed at his pleasure. The governor and adjutant-general make regulations for the government and control of the force, and the governor may disband the force in whole or in part at any time. The Arizona law provides for one company of Arizona rangers, for the protection of the frontier of the territory.

Municipal Home Rule. ${ }^{56}$ - California ${ }^{57}$ submitted a constitutional amendment, to be voted on in 1902 , providing that amendments to home-rule charters must be submitted to popular vote if petitioned for by fifteen per cent of the qualified voters. Under the present constitutional provision there is no provision for popular initiative. Colorado ${ }^{58}$ has submitted to vote an amendment empowering cities of over 2,000 to make, revise and amend their charters, and Oregon ${ }^{59}$ has referred to the next legislature an amendment providing that general laws shall be passed for the incorporation of cities, and that cities may frame and adopt charters without submission to the legislature for approval. Oregon also created a board to prepare a charter for Portland, the charter to be submitted to the voters in June, I902, and if approved by them to be submitted to the legislature for approval or rejection without amendment. ${ }^{60}$ Missouri $^{61}$ has submitted an amendment, modifying its home-rule provision by providing that city law-making authorities may order the popular election of thirteen freeholders, to prepare a new charter for adoption by a majority vote, and Minnesota ${ }^{62}$ has amended its law of 1899 by pro-

${ }^{56}$ See also Dclos F. Wilcox, City Government, in Review of Legislation, rpor, p. 18, New York State Library Legislation Bulletin No. 16.

67 California, I901, p. 950.

68 Colorado, rgor, ch, 46.

${ }^{\circ}$ Oregon, r $90 \mathrm{r}$, p. $47 \mathrm{r}$.

${ }^{60}$ Oregon, rgor, p. 296.

61 Missouri, rgor, p. 263.

62 Minnesota, r9or, ch. 323. 
viding that, on petition of five per cent of the voters, a proposed city charter is to be submitted to popular vote.

As an offset to these measures increasing local home rule and popular initiative, there must be noted the Pennsylvania act, ${ }^{63} \mathrm{com}-$ monly known as the "ripper bill." This act provides a new system of government for cities of the second class, including Pittsburg, Allegheny and Scranton. The office of mayor is abolished and that of recorder established in its place. The recorder is to hold the office for three years, and is not eligible to re-election. He appoints for three years, with power of removal, the heads of departments except comptroller, treasurer and assessor. Subordinate officers are appointed by the heads of departments and salaries fixed by the council. The office of recorder is to become elective in 1903 , but until then is to be filled by appointees of the governor.

Franchises.-A California ${ }^{64}$ act, regulating the granting of franchises, provides for public sale, and that two per cent of the gross annual receipts must be paid to the city after five years. West Virginia $^{65}$ makes it unlawful for a county court or council to grant a franchise till after thirty days' public notice. The term may not exceed fifty years. A constitutional amendment submitted by Colorado ${ }^{66}$ provides that franchises are to be granted only on vote of qualified tax-paying electors.

Municipal Oronership.-In California ${ }^{67}$ an act increases the powers of boards of trustees of cities as to the acquisition of water works, street railways and other public utilities. Arkansas ${ }^{88}$ authorizes municipal corporations to construct gas and electric works, and to furnish light and power to private consumers. In Minnesota ${ }^{69}$ cities under 10,000 may issue four per cent bonds to construct or buy electric-light plants, and in Nebraska, ${ }^{70}$ cities of over 1,000 are authorized to establish heating or lighting systems. Wisconsin ${ }^{71}$ authorizes municipalities to build and maintain a dam for heat, light or power purposes, and to furnish light to parties outside corporate

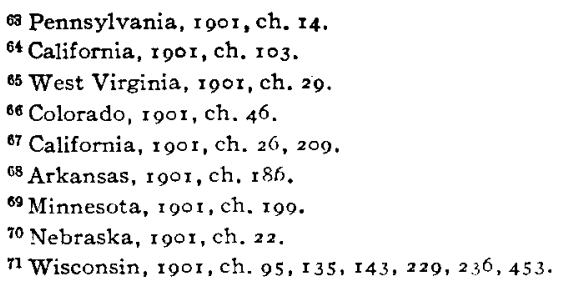


limits. In Wyoming, ${ }^{72}$ municipalities may build, buy and operate light, heat and power plants.

Parks.-Montana ${ }^{73}$ has authorized the governor to appoint six park commissioners in cities of 10,000 . In New Jersey ${ }^{74}$ an act has been passed providing for county park commissioners, but the act is not effective till accepted by the voters of the county. Four park commissioners are to be elected for two years at a salary of $\$ \mathrm{I}, 500$. They are to locate and acquire parks, and may condemn land and assess benefits and damages.

Art Commission.-Minnesota ${ }^{75}$ has provided that cities of over 50,000 may provide for the appointment of an art commission, consisting of five members, for a term of five years. One member is to be from the art society, one selected by the park commissioners, one by the library board, and one must be a painter, sculptor or architect. The commission is to advise with municipality on art questions. ${ }^{76}$ Robert H. WhitTen.

New York State Library, Albany, N. Y.

72 Wyoming, r gor, ch, 22.

T3 Montana, rgor, p. 73.

is New Jersey, rgor, ch. 64 .

${ }^{75}$ Minnesota, r $901, \mathrm{ch}$. 154.

${ }^{76}$ For a more detailed discussion of these subjects see Review of Legislation, rgor. New York State Library Legislation Bulletin, No. 16 . For brief classified summaries of all laws passed, see Comparative Summary and Index of Legislation, New York State Library Legislation Bulletin, No. I 5 . 